\title{
COVID-19 Enfeksiyon Hastalığı Salgınına Biyoetik Açıdan Bakış
}

\author{
Yeşim Işıl Ülman®
}

Acıbadem Üniversitesi, Tıp Tarihi ve Etik, Istanbul, Türkiye

Yeşim Işıl Ülman, Prof. Dr.
Illetişim:

Prof. Dr. Yeşim Ișıl Ülman

Acıbadem Üniversitesi, Tip Tarihi ve Etik,

Istanbul, Türkiye

Tel: +902165004135

E-Posta: yesimul@yahoo.com
Gönderilme Tarihi : 02 Haziran 2020

Revizyon Tarihi : 02 Haziran 2020

Kabul Tarihi : 04 Haziran 2020
ÖZET

Enfeksiyon hastalıkları, hayvandan insana, insandan insana bulaşabilen, tanı konabilir, tedavi edilebilir, iyileştirilebilir ve önlenebilir hastalıklardır. İnsanlarda hastalık, sakatık ve ölüme neden olabildiklerinden, enfeksiyon hastalıklarıyla mücadele önemlidir. Tıp ve bilim tarihi açısından bakıldığında, insanlık, enfeksiyon hastalıklarıyla mücadelede bağışıklama yöntemiyle önemli başarılar elde etmiştir. 2019 Aralık ayında Çin'de ilk kez saptanan yeni koronavirüs (SARS-CoV-2), COVID-19 adı verilen akut solunum yolu enfeksiyon hastalığına yol açmış; kısa sürede dünya üzerinde yayılarak pandemiye dönüşmüş, toplumsal ve ekonomik sorunlara yol açmıştır.

Salgınla mücadelede bilimsel olarak ne yapmak gerektiğini anlamanın yanı sıra bu mücadelenin "nası" yapılacağının, hangi tutum ve davranışlarla yönetileceğinin, bir başka deyişle, meselenin etik boyutunun sorgulanmasına intiyaç vardır. COVID-19 salgını ile mücadelede, kanıta dayalı bilimsel, tıbbi müdahale sürerken; biyoetik açıdan, gelişmelerin açıkıı, şeffaflık ve gerçekçilikle kamuoyuyla paylaşıldığı; herkese eşitlikle muamele edildiği, karantina ve izolasyon durumlarında kişi özerkliğinden, toplum sağlığı adına orantılı, ölçülü fedakarlık beklendiği; insanlar, hastaneler, birimler ve ülkeler arasında dayanışma ve işbirliğinin desteklendiği; hükümetlerin hesap verilebilirlikle halkın intiyaçlarına cevap verebildiği, iktisadi hayatın karşılıklı işbirliği ve dayanışma ile desteklendiği, insan haklarına ve onuruna uygun; insani, çoğulcu, çevreye, biyosfere, biyoçeşitliliğe, gelecek nesillere saygllı ve sorumlu tutum ve davranışlarla salgın yönetimi önerilir.

Anahtar sözcükler: Etik, biyoetik, halk sağlı̆ı, enfeksiyon hastalıkları, COVID-19 Pandemisi

\section{A BIOETHICAL PERSPECTIVE FOR COVID-19 INFECTIOUS DISEASE PANDEMIC}

\section{ABSTRACT}

Infectious diseases are major public health concerns as they cause deaths, disabilities, and provoke epidemics and pandemics. Although they are transmitted from animal to man, from man to man by pathogenic microorganisms, they are detectable, curable, and preventable diseases. Historically there have been significant scientific achievements whilst struggling with infectious diseases by means of immunization, such as smallpox, chickenpox vaccinations. As a matter of fact, the COVID-19 infectious disease which was caused by novel coronavirus (SARSCoV-2) was first detectable in China in December 2019, and it soon triggered a global pandemic spreading most continents and countries world wide. As well as understanding what to do in scientific, medical, legal, economic, sociological aspects in the fight against the pandemic, there is a need to question "how" this struggle should be conducted. This takes us to analyze the ethical dimension of the issue, according to bioethics principles.

In the fight against the COVID-19 outbreak, while evidence-based scientific and medical interventions continue; bioethics recommends that all developments should be shared with the public with accountability, transparency, integrity; everyone should be treated equally; individual autonomy should be proportionally balanced with the public beneficence under the circumstances of quarantine and isolation; solidarity and cooperation should be promoted between people, hospitals, centres and countries; economic life can be supported by mutual cooperation and solidarity; governments should respond to the needs of the people with justice and fairness; outbreak policies and strategies should be managed in the light of humanitarian, pluralistic, democratic vision; respect to environment, biosphere, biodiversity should be considered responsibly all in line with human rights and dignity.

Keywords: Ethics, bioethics, public health, infectious diseases, COVID-19 Pandemic 
E nfeksiyon hastalıkları, mikroorganizmaların sebep olduğu, hayvandan insana, insandan insana bulaşabilen, tanı konabilir, tedavi edilebilir, iyileştirilebilir ve önlenebilir hastalıklardır. Insanlarda hastalık, sakatlık ve ölüme neden olabildiklerinden, enfeksiyon hastalıklarıyla mücadele önemlidir. Epidemiye (belli bölgeyi etkileyen salgınlara) veya pandemiye (birden çok kıtayı etkisi altına alan salgınlara) yol açabilirler. Bugün dünyada, örneğin su çiçeği gibi çocukluk çağı enfeksiyon hastalıkları ile mücadelede, aşıyla, bağışıklama yoluyla büyük bilimsel ilerleme kaydedilmiştir. Ancak, dünyada, son yirmi yılda Ebola, SARS, Kuş Gribi (H5N1), MERS (1) ve son olarak da COVID-19 gibi birçok yeni enfeksiyon ortaya çıkarak ölümlere yol açmıştır.

\section{Koronavirüs (COVID-19) hastalığı ve pandemiye dönüşs süreci}

2019 yılı Aralık ayında, Çin'in Wuhan, Hubei bölgesinde, klinik tablosu viral pnömoniye benzeyen, yeni bir dizi olgu saptanmıştır. Yapılan genetik analizde, yeni bir koronavirüs türü (SARS-CoV-2) enfeksiyonu ile karşılaşıldığı anlaşılmıştır (2). Wuhan'da ortaya çıktıktan kısa süre sonra Çin'in bazı eyaletleri, Tayland, Japonya, Güney Kore ve $A B D$ 'de görülen ve koronavirüs ailesinin biyolojik değişime uğramış yeni bir formu olan bu virüsün yol açtığı hastalığa COVID-19 adı verilmiştir. Akut solunum yolu enfeksiyonu olarak tanımlanan COVID-19 enfeksiyonu, daha önce de salgınlara yol açmış olan, SARS (Severe Acute Respiratory Syndrome) veya MERS (Middle East Respiratory Syndrome)'den farklıdır. Daha hızlı bulaşmakta, daha ağır seyretmekte; ileri yaş, altta yatan hastalık gibi faktörlerle birlikte ölümcül olabilmektedir (3).

Hastalık kısa sürede dünya sathına yayılmış; Dünya Sağlık Örgütü (DSÖ), 11 Mart 2020 tarihinde, Yeni Korona Virüs Enfeksiyonunun küresel pandemiye yol açtığını resmen ilan etmiştir (4). DSÖ'nün bu duyurusu, salgınla mücadele etmek üzere, dünya ülkelerinin sınırlarını kapatma, uçuşları durdurma, sosyal mesafe, karantina gibi tedbirleri hızla hayata geçirmeleri uyarısı anlamına geliyordu. Bilim insanları yeni ortaya çıkan bu enfeksiyon hastalığının, yapısını, etkisini, bulaş yollarını anlamaya çalışırken; Çin, yaklaşık 50 milyon nüfuslu bölgeyi karantina alarak, salgının ülkede yayılmasını önlemeye çalışmıştır (5). Ancak tanı alanların ve kayıpların sayısı hızla yükselmiş; DSÖ kayıtlarına göre, 4 Haziran 2020 itibarıly, pandemi dünya üzerinde Antarktika hariç yüm kıtalara ve yaklaşık 215 ülkeye yayılmış, 6,652,446 kişiye COVID-19 tanısı konulmuş, 390,575 insan kaybedilmiştir (6).

\section{Salgının yol açtığı, toplumsal, bireysel, sağlıkla ilgili sorunlar}

COVID-19 pandemisi etkisiyle, durdurulan ulaşım, kapanan sınırlar, okullar, sosyal mesafelenme, karantina, sokağa çıkma yasakları, sıkı hijyen tedbirleri ile birlikte dünya genelinde içe kapanma hali ortaya çıkmıştır. Bunu iş kaybı, geçim zorluğu, fakirleşme, daralan ülke ekonomileri, esnek çalışma düzeni, evden çalışma ve getirdiği iş yükü; şiddet, ev içi şiddet, birey ruh sağlığı sorunları; istikrarsızlık, huzursuzluk gibi toplumsal ve ekonomik meseleler izlemiş̧ir (7).

Sağlık ortamında ise COVID-19 hastalarının öncelenmesi, artan olgular, kayıplar, beklenmedik bir yükle karşılaşan sağlık sistemleri, ağır yük altında hizmet veren sağlık çaıışanları, sağlık çalışanlarının koruyucu malzeme ihtiyacı, tanı kitlerinin yaygınlaştırılması, tıbbi izlem, temaslı taraması; sağlık çalışanlarının bir yandan hizmet sunarken bir yandan da kendilerini ve yakınlarını koruyabilmeleri gibi sorunlar gündeme gelmiştir. Biyoetik uzmanı Huxtable'ın dikkat çektiği gibi, salgın nedeniyle artan talep karşısında sınırlı kaynakların (malzemeler, cihazlar, insan gücü vb.) dağıtımı, tedavi önceliklerin belirlenmesi, yoğun bakım hizmetlerinin yeterliliği, bakımevlerindeki durum gibi etik meseleler (8) öne çıkmıştır.

\section{Salgına etik yaklaşım}

Salgın hastalıkla mücadelede bilimsel, tıbbi, hukuki, ekonomik, sosyolojik açılardan ne yapmak gerektiğini anlamanın yanı sıra bu mücadelenin "nası" yapılacağının yani, hangi tutum ve davranışlar gözetilerek verileceğinin, bir başka deyişle, meselenin etik boyutunun da sorgulanmasına ihtiyaç vardır. COVID-19 pandemisi mücadelesinde salgını kontrol altına alabilmek için, kanıta dayalı bilimsel bilgiyle hareket ederek, planlı, zamanında, hızlı karşılık vermek gerekir. Salgın gibi dinamik ve değişken seyreden, henüz hastalığın aşısı ve tedavisinin bulunmadığı, bilimsel araştırmaların yoğunlukla yürütüldüğü süreçte; hizmetlerin dağıtımı, dezavantajlı gruptaki insanlara yaklaşım, bağışıklık meselesi, sağlık sistemlerinin etkili biçimde yönetimi tutum ve değerler yönüyle ele alınmalıdır.

Fritz ve ark.'nın önerdiği gibi, ülke içinde, uluslararası sistemle bütünleşik, şeffaflıkla işleyen, bilgilerin erişilebilir olduğu, sağlık hizmeti sunumu ve stratejilerinin açık, tutarlı, alınan kararların savunulabilir olduğu, tüm tarafların temsiliyetinin sağlandığı, kamuyla paylaşılan etik ilkeleri kılavuz alan bir koordinasyona ihtiyaç vardır. Sağlık sistemine içkin, sosyal bakım merkezlerini de kapsayan klinik etik danışmanlık hizmetlerinin varlığına ve yaygınlaştırılmasına intiyaç vardır. Toplum ve sağlık politikalarının etik kurallar 
ışığında örgütlenerek işlemesi önemlidir (9). Bu bağlamda, salgının en çok etkili olduğu bölgelerde, tıbbi sorunların yanı sıra sağlığın toplumsal belirleyenlerinin de, sağlık hakkına erişimin koşullarının da göz önüne alınması bütünlüklü mücadele açısından önemlidir. Salgınla ilgili her türlü müdahalede etik ilkeleri yükselten yaklaşım, nitelikli sağlık hizmetinin ayrılmaz parçasıdır. Salgının yarattığı sorunlarla mücadelede etik olarak kabul edilebilir çözümler ararken, insan hakları ve insan onuru temeline dayanan tüm canlılar ile ilgili değer sorunlarını kavrayan biyoetik ilkeler yol göstericidir. Bu çözümlemede UNESCO Evrensel Biyoetik ve İnsan Hakları Bildirgesi ilkelerinden yararlanılabilir (10).

\section{Salgın yönetimi, planlanma, halk sağlığı, şeffaflık, hesap verilebilirlik, güven}

Salgınlar gibi olağandışı dönemlerde, tek tek bireylerin sağlığından öte, tüm toplumun sağlığına odaklanan; tüm nüfusun sağlığını koruma, geliştirme, hastalıkları, sakatlığı önleme (11) hedefleriyle çalışan halk sağlığı uzmanlığı önem kazanır. Salgın yönetiminde, halk sağlığı disiplininin, sağlığın sosyal belirleyecilerini dikkate alan, epidemiyolojik araştırmalar, nüfus istatistikleri, ampirik risk değerlendirmelerinden yararlanan (12) yöntemleri üzerine inşa edilecek bilimsel veri tabanına dayanan stratejileri dikkate alıır, etik ilkelerle dengelenir. Salgın kontrolü ve yönetiminde, insan ve toplum sağlığı yararına tasarlanmış, çok disiplinli ve tüm tarafların eşitlikle temsil edildiği karar süreçleri ile çalışan, çoğulcu, şeffaf, hesap verilebilir, adil kamu politikaları ve stratejileri üreten; akılc muhakeme ile gecikmeden etkili yanıt verebilen, kamuoyunda güven yaratan, demokratik işleyişe intiyaç duyulur. Bu bağlamda dünya genelinde ülkelerin izlediği halk sağlığı politikaları ve toplumsal bağışıklık stratejileri irdelenmiş, uygulama örnekleri yoğun tartışma konusu olmuştur. Halk sağlığı uzmanları, salgınla mücadele yöntemlerinde baskılama ve hafifletme (mitigation-suppression) stratejilerinin dengeli kullanılmasına, toplumsal bağışıklığın aşı ile birlikte eş zamanlı yürütülmesine dikkat çekmektedir (13). Etik bakış açısı, toplumsal bağışıkık stratejilerinde, insan ve toplum sağlığı açısından yarar zarar dengesinin akılcı biçimde kurulmasını önemsemekte; aşı ve tedavinin araştırmalarının sürdüğü günümüz koşullarında ileri yaş gruplarının yüksek risk ve zararına (14) yol açabilecek uygulamaları ise eleştirmektedir.

\section{Salgınla ilgili politika ve stratejilere etik yaklaşım}

Herkesin, insan hakları hukuku ve meslek etiği ilkeleri doğrultusunda, bireysel ve toplumsal bir hak olarak sağlık hizmetine erişiminin eşitlikle ve hakkaniyetle, sağlanması önemlidir (15). Etiğin adalet ve eşitlik ilkeleri ışı̆̆ında, halkın sağlığını ve güvenliğini koruma sorumluluğunu yerine getirmek, bunu güvence altına almak üzere tedbirler geliştirmek ve salgın anında aşırı yüklenebilen sağlık sistemine destek sağlayan politikalar uygulamak yöneticilerin görevidir.

Yöneticiler, politika belirleyenler tarafından, karantina ve sosyal mesafe stratejileri uygulanırken, toplumda herhangi bir gruba karşı yanlılık yaratmayan, gelir ve iş kaybına uğrayanların zararını tazmin eden tedbirlerin hızla hayata geçirilmesine ihtiyaç vardır. Toplumda, kimsesizler, bakıma muhtaç olanlar, evsizler, özgürlüğü kısıtlı olanlar, tutuklu ve hükümlüler, engelliler, göçmenler gibi savunmasız durumdaki grupları koruyucu politikalar oluşturulmalıdır. Aynı durum COVID-19 tanısı dışında tedavi görmekte olan insanların desteklenmesi için de geçerlidir. Salgının yönetiminde, halk sağlığı politikalarının, kurumlarının ve yöneticilerin, kamu yararı adına bireysel özgürlüklerinden fedakârlık eden yurttaşlara, karşılıklıık prensibi gereği (16), kanıta dayalı, olgu temelli, saydam bir işleyiş ve iletişim kurarak güven yaratmaları önemlidir (17). Bireyler de, bulaşı önlemek üzere, hijyen tedbirleri, maske takma, toplumsal hareketliliklerini kısıtlama, evde kalma, sosyal mesafeyi koruma, karantina kurallarını uygulama gibi yollarla bireysel ve toplumsal sorumluluklarını yerine getirmelidirler (18).

\section{Sağlık çalışanlarının hizmet verme yükümlülüğü}

Sağlık politikalarını belirleyenlerin, öncelikle, makro düzeyde, sağlık çalışanlarının, kısıtlı kaynaklar altında hastaları için zor seçimler yapmak durumunda kalmamalarını önceden öngörüp; olağan durumda iken hazırlıklı olup, intiyacı olana eşitlikle kaynak dağıtımı yapmış olmaları önemlidir. Bu tür sağlık krizi durumlarında, insanların evde kalmaları (19), COVID-19 belirtileri haricinde acil olmayan tıbbi başvurularını ertelemeleri, sağlık sistemine baskıyı hafifleterek, destek sağlar. Sağlık çalışanlarının hekimlik meslek etiği ilkeleriyle yaşam hakkını korumak üzere ve hakkaniyetle hizmet sunabilmeleri için ihtiyaç duydukları her türlü kaynak, ortam, klinik testler ve olanakların temin edilmesi ve yaygınlaştırılması önemlidir ve yöneticilerin sorumluluğundadır (20).

Türk Tabipleri Birliği bu bağlamda COVID-19 salgını esnasında hekimlerin karşılaştıkları zorluklar, hekimlerin (sağlık çalışanlarının) hak ve yükümlülükleri, Sağlık Bakanlığı ve işverenlerin sorumlukları konusunda açıklama yapmıştır (21). Virüse yüksek ölçüde maruz kalan sağlık çalışanlarına, kendilerini ve yakınlarını korumak üzere ihtiyaçları olan salgınla mücadele eğitimi, koruyucu 
elbise, maske, eldiven ve benzeri imkânların sağlanması; insani çalışma koşulları, mesleki güvence, dinlenme gibi temel özlük haklarının güvenceye alınması, meslek etiği ilkelerine bağlı olarak (22) çalışabilmelerinin sağlanması, anayasal sosyal devlet ve toplum sözleşmesi anlayışı ile çalışan devletin görevidir. 31 Mayıs 2020 tarihi itibarıyla, dünya genelinde, ön hatta çalışan 1000'i aşkın sağlık profesyonelinin hayatlarını kaybettikleri bildirilmektedir (23). Salgının ilk görüldüğü Çin'den yapılan araştırmada, kaybedilen 23 sağlık çalışanının ortalama 55 yaşında olduğu, 17'sinin erkek, 6'sının kadın olduğu; çeşitli uzmanlık alanlarından 13'ünün doğrudan hastaya hizmet verirken hastalığa yakalandığı, hastalıktan korunmada koruyucu ekipmanın ve tedbirlerin hayati önemde olduğu belirtilmiştir. Çin'de hastalığı ilk fark ederek, önemine dikkat çeken Dr. Li Wenliang (1985-2020), bu beyanı nedeniyle devlet yetkilileri tarafından uyarılmıştı. Daha sonra haklı olduğu görülmüş, susturulmasının hastalığa erken müdahalede gecikmeye sebep olduğu anlaşılmıştı. Çin Devleti kendisinden resmen özür dilediğinde ise, Dr. Li, COVID-19 nedeniyle çoktan hayatını kaybetmiş bulunuyordu (24).

Biyoetikçi Fenton, koruyucu elbise ve malzemelerin temininin tartışmasız bir etik zorunluluk olduğunu belirtmektedir (25). Bir başka biyoetikçi Udo Schuklenk, sağlık çalışanlarının, eksik, hatalı sağlık politikaları ve stratejileri uyarınca, salgınla mücadelede yetersiz ve hazırlıksız koşullardaki hastanelerde, koruyucu elbise ve korunma olanaklarından yoksun, aşırı iş yükü altında hizmet vermeye zorlanmalarını eleştirmekte, bu durumun etik açıdan savunulamayacağını ifade etmektedir (26).

\section{Sınırlı kaynakların hakkaniyetle dağıtımı}

Etik açıdan, sağlık çalışanlarını zor ikilemlerde bırakmamak üzere; yukarıda değinildiği gibi, sağlık politikalarını belirleyenlerin görevi, makro düzeyde kaynak ve pay aktarımını, olağandışı koşullarda adil ve eşit biçimde sağlık hizmeti sunabilecek şekilde önceden planlamış olmaktır. Sağlık çalışanları ancak bu şekilde herkese ihtiyacı olan tıbbi bakımı, acil desteği, yoğun bakım hizmetini eşitlikle ve adaletle sunabilirler. Ancak kaçınılmaz olarak bu kararların verilmesi gerektiği anlar gelebilir ve hekimlerde etik kaygı (moral distress) yaratan, onulmaz etik hasar (moral damage, moral injury) bırakan zorlu tercihler yapılmak zorunda kalınabilir. Bu durumda, yararlı olma (mümkün olduğunca çok sayıda insanın yararı için hareket etme) ve eşitlik (herkese ihtiyacı olan tedaviyi eşit ölçüde verme) biyoetik ilkeleri arasında ikilem yaşanabilir. Amerikan Acil Hekimlik ve Etik Kılavuzu, sağlık sisteminin aşırı yük altında olduğu salgın gibi olağanüstü durumlarda, acil tıp uzmanlarına, sağkalım olasılığı en yüksek olan en çok sayıda insanın kurtarılması yönünde triyaj kararı önermektedir (27). Amerikan Tıp Birliği, sınırlı kaynakların dağıtımında, acil bakım dahil tıbbi intiyaca göre, en çok yarar sağlama ihtimali olana, en yüksek yaşam kalitesi ihtimali olana öncelik vermeyi; erken ölümü önlemeyi tercih etmeyi; nesnel, esnek, saydam süreçlerle karar almayı; hastaları ve kamuoyunu süreç hakkında bilgilendirmeyi tavsiye etmektedir (28). Emanuel ve ark., hakkaniyetli davranmak için, mümkün olduğunca çok kişiye yarar sağlamayı, çok sayıda hayat kurtarmayı, prognozu uzun olana öncelik vermeyi, herkese eşit özenle davranmayı, «ilk gelene hizmet ver» kuralını uygulamamayı, benzer prognozu olan hastalarda rastlantısal seçim yapmayı, başkalarına yarar sağlayanlara (sağlık çalışanları, araştırma gönüllüleri, vb.) öncelik vermeyi, en çok zarar göreni öncelemeyi, durumu en ağır olanı (en ağır hastayı ve salgının yayılmasını önlerken en genç hastayı) önce almayı, tıbbi kriterleri iyi değerlendirmeyi, hem COVID-19 hastasına hem de olmayana bu ilkeleri uygulamayı önermektedirler (29).

White ve ark. ise, halkın sağlığını tehdit eden acil bir hastalık durumunda, sınırlı sayıdaki solunum cihazının hangi hastaya verileceği kararını alırken, mümkün olduğunca çok sayıda hayat kurtarmayı, önünde daha çok yılı olana öncelik vermeyi (komorbiditeyi değerlendirerek), yaşam döngüsü kriterini (yaşa bağlı uzun yıllar yaşama olasılığı az olanı) öncelemeyi önermektedir (30). Dünya Sağlık Örgütü'nün Enfeksiyon Hastalıkları Salgınında Etik Meseleleri Yönetme Kılavuzu'nda ise temel olarak yararlı olma ve eşitlik ilkelerinin dengelenmesi önerilmektedir. Kılavuz, kaynak dağıtımı ve önceliklerin belirlenmesinde, ister toplam yaşam süresi, ister toplam sağlıklı yaşam süresi, isterse de yaşam kalitesi uzunluğu kriteri göz önüne alınsın, her zaman tıbbi yarar sağlama ilkesinin öncelenmesini önemli görmektedir. Toplumda, hayati görevleri yerine getirenler hariç olmak üzere, insanları toplumsal değer üzerinden değerlendirmeyi etik bulmamaktadır. Toplumda, ayrımcılığa, damgalanmaya, dışlanmaya maruz kalabilecek, risk altındaki insanları daha fazla korumayı gerekli bulan DSÖ kılavuzu, bu süreçte, karşıııkııık prensibiyle, şeffaflıkla, hesap verilebilirlikle; suistimale kapalı olarak, güven yaratıcı, sorumlulukla, tıbbi yetkinlikle davranmayı önemli görmektedir (31). Etik açıdan kimseyi arkada bırakmadan, ihmal etmeden, herkese ihtiyacı olan bakımı verebilmek önemlidir. Bunu mümkün kılmak için de önceden hazırlıklı olmak hayati derecede önem taşır. 


\section{Savunmasız gruplar ve ayrımcilık yapmama, damgalamama}

Olağan dönemlerde savunmasız, örselenebilir kabul edilen bireyler, salgın gibi olağanüstü durumlarda daha da korunmasız duruma düşerler. Illeri yaştakiler, bakıma muhtaç olanlar (32), engelliler, yoksullar, özgürlüğü kısıtlı olanlar (mahkûmlar, tutuklular), mülteciler gibi topluluklar, her zamankinden daha fazla risk altındadırlar (33). Savunmasız durumdaki bu insanların korunmasında, sözel ya da fiziksel hiçbir ayrımcılık ve damgalamaya uğramamaları için ortak sorumlulukla, adaletle davranılmalıdır. Salgın nedeniyle başvurulan izolasyon, karantina gibi önlemler, bu örselenebilir gruptaki insanları daha da ağır etkileyebilir. Bu nedenle uygulanan salgın yönetimi stratejilerinin ayrımcılık ve damgalama içermemesi çok önemlidir. Pandemi koşullarının yarattığı endişe ve içeride kısıtlı kalmadan dolayı ortaya çıkan yalnızlık, endişe, anksiyete, korku gibi psikolojik sorunlarla başa çıkmak üzere danışmanlık, destek hizmetleri ve tedbirleri örgütlenmelidir (34).

\section{Kadına yönelik şiddet ve toplumsal cinsiyet eşitsizliği}

Ev içi şiddete açık ya da ekonomik olarak darda, toplumsal cinsiyet eşitsizliği mağduru kişileri korumak ve kollamak üzere ve bu durumdaki kişilerin zarar görmemeleri için etkili ve yeterli çaba harcanmalıdır. İçinde bulundukları durumun daha da kötüleşmemesi için yasal düzenlemeler ve hukuki yaptırımlarla çeşitli destek, önlem ve yardım stratejileri uygulanmalıdır. Roesch ve ark., hükümetlerin, şiddet gören kadının başvuracağı, yararlanacağı kanalları açık ve işler tutmasına, şiddet mağdurlarına tıbbi destek, danışmanlık, cinsel saldırı sonrası bakım, sığınma evi, danışmanlık hizmeti gibi desteklerin sağlamasına; sağlık çalışanlarının, kadına yönelik şiddetin farkında olmalarına, mağdurun durumuna uygun destek ve tedavi sağlamalarına, yaşlı, mülteci, etnik azınlıktaki kadınlara ihtiyaçlarına uygun bakım vermelerine; kadınların telefon, internet gibi acil destek, hizmet olanaklarından yararlanabilmelerine, COVID-19'dan korunma koşullarına uygun tedavi alabilmelerine dikkat çekmişlerdir (35). Ülkemizde, Kadın Cinayetlerini Durduracağız Platformu, salgın nedeniyle evde kalma zorunluluğu ile birlikte, Türkiye'nin yakıcı sorunlarından biri olan kadına yönelik şiddet ve istismar olgularında artışa dikkat çekmiş; hazırladığı Korona Günlerinde Şiddetten Korunma Kılavuzu'nda (36), ülkemizin taraf olduğu uluslararası sözleşmeler ile yerel hukuki mevzuatın uygulamasının yaygınlaşması ve güçlendirilmesi ihtiyacına dikkat çekmiştir.

\section{Mahremiyet ve özel hayatın gizliliği}

Mahremiyete ve özel hayatın gizliliğine saygı, uluslararası sözleşmeler ve yerel hukuk mevzuatı güvencesinde olan temel insan hakkıdır. Salgın hastalığı önleme tanı, tedavi süreçlerinde, bununla ilgili bilimsel araştırmalarda elde edilen tıbbi veriler de aynı kapsamdadır. Bununla birlikte, toplanan tıbbi verilerin, hem insan hem de toplum sağlığı açısından; yine önleme, tanı, tedavi, bilimsel araştırma amaçlı olarak paylaşılması, mahremiyet ilkesinin kırılabilmesinin etik olarak savunulabildiği durumdur. COVID-19 ile mücadelede, insan sağlığı, toplum sağlığı izlemine, büyük veri tabanından yararlanmak isteyen bilimsel araştırmaların yürütülmesine ihtiyaç vardır. Bu temel insan hakkının kamu yararı adına ölçülü biçimde sınırlandırıması etik açıdan haklı çıkarılabilir (37). Ancak paylaşım mutlaka tıbbi ve bilimsel amaçlı olmalı, kimlik bilgileri saklanmalı ve erişimi yetkililerle sınırlı olmalıdır.

Bilimsel araştırmalarda alınan insan kaynaklı ürünler (örnekler) anonimleştirilerek saklanmalı; öncesinde hastanın, sağlıklı gönüllünün Aydınlatılmış Onamı alınmalıdır (38). Bu nedenle hastalığın temaslı taraması, filiasyon ve benzeri halk sağlığı tedbirleri için teknik elektronik takip, yapay zekâ sistemlerini kullanma, yüz tanıma modunu çalıştırma, çeşitli web applikasyonları, ancak önceden haber ve bilgi verilerek gerekçeli olarak yapılabilir; acil durum ortadan kalkınca durdurulmalıdır.

\section{Bilimsel araştırmalar ve etik}

Salgınla mücadelede hastalığın tanısı, tedavisi, korunma yolları, aşılar konusunda bilimsel araştırmaların yürütülmesi hayati önem taşır. Hem bilimsel araştırmaları değerlendirmek hem de sağlık çalışanlarına, hastalara ve yakınlarına klinik etik desteği sunmak üzere etik kurullar görev başında olmalıdırlar. Pandemi, doğal afet ve benzeri gibi olağanüstü durumlarda bu çalışmaların önünü açmak ve hızlandırmak önemli bir gereksinim ve toplum sağlığı açısından bir gerekliliktir. Ancak bu, etik kuralların ihlaline göz yummak anlamına gelmez. Bu araştırmalar da Dünya Tabipleri Birliği Helsinki İnsanlar Üzerinde Araştırma ve Deneyler Bildirgesi ve İnsan Hakları ve Biyotıp Sözleşmesi (39) kurallarına bağlı olarak yürütülür. Ayrıca COVID-19 enfeksiyon hastalığının aşısı ve tedavisinin, biyoetiğin 'yararın paylaşılması' ilkesi ışı̆̆ında, tüm ihtiyacı olanlara erişiminin sağlanması ve paylaşılması önemlidir.

COVID-19 aşısı ve tedavisi araştırmalarının yürütülmesinde yüksek toplumsal fayda, gönüllülerin sağlığının azami ölçüde korunması, yarar-zarar dengesinin iyi yapılması esastır. Adil biçimde, genç, sağlıklı, erişkin ve yeterlik sahibi 
sağlıklı gönüllülerle araştırma yürütülmelidir. Gönüllülerin katlanacakları külfet ve riskin en aza indirilmesi denetlenmelidir. Gönüllüler tam, ayrıntılı, kapsamlı şekilde bilgilendirilmeli, aydınlatılmalı (robust informed consent), onamlarına başvurulmalıdır. Öngörülen riskin üzerinde durum gelişirse derhal müdahale edilerek, gönüllü korunmalıdır. Araştırmalar, güven yaratan şeffafık, hesap verilebilirlikle yürütülmelidir. Araştırmanın güvenli olarak yürütülebileceği alt yapı, yüksek güvenlikli laboratuvar ortamı ve denetimi sağlanmalıdır. Kamuoyuna karşı sorumlulukla ve hesap verebilirlikle davranılmalıdır. Gönüllülere, ayıracakları zaman, emek, risk ile orantılı ve ölçülü bir ücretlendirme sağlanabilmelidir (40). Hayvanlar üzerinde araştırma ve deneylerde de bilimsel ve etik ölçütlerin sağlanması, 3R kuralının tam olarak uygulanması esastır.

\section{Dayanışma, çoğulculuk, insan hakları ve onuru, gelecek nesillere sorumluluk}

Salgın yönetiminde açılma yöntemlerinin tartışıldığı şu günlerde, salgının hala sürmekte olduğu ve etkisini devam ettirdiği unutulmadan, açılma stratejilerinin de benzer ilkelerle yürütülmesine ihtiyaç vardır. Salgının en çok etkili olduğu bölgelerin, sağlığın toplumsal belirleyenleri olan, yaş, cinsiyet, çalışma koşulları, işsizlik, yoksulluk, ayrımcılık; temiz suya, gıdaya, konuta, sağlıklı çevreye erişim; geçim, eğitim gibi etkenler (41) ile bağlantılı olduğu

\section{Kaynaklar}

1. Jacobson JA. Infectious diseases ethics. In: Singer PA, Viens AM, editors. Cambridge Textbook of Bioethics, 3rd ed. NY: Cambridge University Press; 2009. p.481-6. https://www.dphu.org/uploads/ attachements/books/books_5318_0.pdf

2. Huang C, Wang Y, Li X, Ren L, Zhao J, Hu Y, et al. Clinical features of patients infected with 2019 novel coronavirus in Wuhan, China. Lancet 2020;395:497-506. [CrossRef]

3. CDC, Coronavirus Disease 2019 (COVID-19); American Thoracic Society What is COVID-19? Worldometer Age, Sex, Existing Conditions of COVID-19 Cases and Deaths. Erişim tarihi: 01.06.2020. https://www.worldometers.info/coronavirus/ coronavirus-age-sex-demographics/

4. WHO Timeline - COVID-19. https://www.who.int/news-room/ detail/27-04-2020-who-timeline---covid-19 Erişim tarihi: 01.06.2020.

5. Klugman C. Ethics of Pandemics: Coronavirus and Large Scale Quarantine. Bioethics Net 2020. http://www.bioethics.net/2020/01/ ethics-of-pandemics-coronavirus-and-large-scale-quarantine/ Erişim tarihi: 01.06.2020

6. WHO Worldometer. https://www.worldometers.info/coronavirus/ Erişim tarihi: 31.05 .2020

7. United Nations, Department of Economic and Social Affairs Social Inclusion, Everyone Included: Social Impact of COVID-19. https:// www.un.org/development/desa/dspd/everyone-includedcovid-19.html Erişim tarihi: 01.06.2020 dikkat çekicidir. Bu toplumsal eşitsizlikleri giderecek şekilde kaynak dağıtımının yapılması, yöntemler geliştirilmesi gerektiği açıktır. Aksi halde, günümüzde dünya genelinde çok sayıda örneğinde gözlendiği gibi, küresel salgın, toplumsal eşitsizlikleri ve ayrımcılığı gün yüzüne çıkarmaktan (42) geri durmayacaktır.

Sonuç olarak, içinde bulunduğumuz küresel sağlık krizi ile mücadelede, kanıta dayalı bilimsel, tıbbi müdahale sürerken; biyoetik açıdan, gelişmelerin açıklık, şeffaflık ve gerçekçilikle kamuoyuyla paylaşıldığı; herkese eşitlikle muamele edildiği, karantina ve izolasyon durumlarında kişi özerkliğinden, toplum sağlığı adına orantılı, ölçülü fedakarlık beklendiği (43); insanlar, hastaneler, birimler ve ülkeler arasında dayanışma ve işbirliğinin desteklendiği; hükümetlerin hesap verilebilirlikle halkın ihtiyaçlarına cevap verebildiği; iktisadi hayatın karşılıklı işbirliği ve dayanışma ile desteklendiği, insan haklarına ve onuruna uygun; insani, çoğulcu, çevreye, biyosfere, biyoçeşitliliğe, gelecek nesillere saygılı ve sorumlu tutum ve davranışlarla salgın yönetimi önemlidir.

\section{Teşekkür}

Tüm dünyada, salgınla mücadele ederken hayatlarını kaybeden sağlık çalışanlarına ve diğer görevlilere sonsuz minnetimi ifade etmek isterim. Yazıyı titizlikle gözden geçirerek; kıymetli, yapıcı görüşlerini paylaşan hakemlere çok teşekkür ederim.

8. Huxtable R. COVID-19: where is the national ethical guidance? BMC Med Ethics 2020; 21:1-3. [CrossRef] https://doi.org/10.1186/s12910020-00478-2 Erişim tarihi: 01.06.2020

9. Fritz Z, Huxtable R, Ives J, Paton A, Slowther AM, Wilkinson D. Ethical road map through the covid-19 pandemic. BMJ 2020;369:m2033. [CrossRef]

10. Unites Nations UNESCO Universal Declaration on Bioethics and Human Rights, 19 October 2005 http://portal.unesco.org/en/ ev.php-URL_ID=31058\&URL_DO=DO_TOPIC\&URL_SECTION=201. html Erişim tarihi: 01.06.2020

11. Kass NE. An Ethics Framework for Public Health. Am J Pub Health 2001;91:1176-82. [CrossRef]

12. Childress J, Faden RR, Gaare RD, Gostin LO, Kahn J, Bonnie RJ, et al. Public Health Ethics: Mapping the Terrain. J Law Med Ethics 2002;30:170-8. [CrossRef]

13. Kayı I, Sakarya S. Policy Analysis of Suppression and Mitigation Strategies in the Management of an Outbreak Through the Example of COVID-19 Pandemic. Infect Dis Clin Microbiol 2020;2:30-41. [CrossRef]

14. Veatch RM. Ethics of Promoting Herd Immunity. Fam Community Health 1987;10:44-53. [CrossRef]

15. Council of Europe Committee on Bioethics: COVID-19: Human rights principles must guide health decisions https://www.coe.int/en/ web/bioethics/-/covid-19-human-rights-principles-must-guidehealth-decisio-1 Erişim tarihi: 01.06.2020 
16. Upshur R. The Ethics of Quarantine. Virtual Mentor 2003;5:393-5. [CrossRef]

17. Lewnard JA, Lo NC. Scientific and ethical basis for social-distancing interventions against COVID-19. Lancet Infect Dis 2020;20:631-3. [CrossRef]

18. Lei R, Qiu R. Report from China: Ethical Questions on the Response to the Coronavirus. Hastings Center Bioethics Forum Essay. The Hastings Center 2020. https://www.thehastingscenter.org/reportfrom-china-ethical-questions-on-the-response-to-the-coronavirus/ Erişim tarihi: 01.06.2020.

19. Le TT, Andreadakis Z, Kumar A, Román RG, Tollefsen S, Saville M, Mayhew S. The COVID-19 vaccine development landscape. Nat Rev Drug Discov 2020;19:305-6. [CrossRef]

20. UNESCO Universal Declaration on Bioethics and Human Rights, 19 October 2005. Erişim tarihi: 18.04.2020. https:// en.unesco.org/themes/ethics-science-and-technology/ bioethics-and-human-rights

21. TürkTabipleri Birliği COVID-19: Hekimlerin (Sağlık Çalışanlarının) hak ve yükümlülükleri, Sağlık Bakanlığı ve işverenlerin sorumluklarl; 3 Nisan 2020. https://www.ttb.org.tr/haber_goster.php?Guid=70e89cf675a2-11ea-b329-aa051764b049 Erişim Tarihi: 01.06.2020.

22. Slowther A, Mitchell S. COVID-19: In focusing on intensive care we must not lose sight of the wider professional duty to care for all patients. J Med Ethics April 3, 2020. Erişim tarihi: 01.06.2020. https://blogs.bmj.com/medical-ethics/2020/04/03/covid-19-infocussing-on-intensive-care-we-must-not-lose-sight-of-the-widerprofessional-duty-to-care-for-all-patients/

23. Medscape, In Memoriam: Healthcare Workers Who Have Died of COVID-19. April 1 2020. https://www.medscape.com/ viewarticle/927976 Erişim: 01.06.2020

24. Lei R, Qiu R. Chinese Bioethicists: Silencing Doctor Impeded Early Control of Coronavirus. The Hastings Center 2020. https://www. thehastingscenter.org/coronavirus-doctor-whistleblower/ Erişim tarihi: 01.06.2020.

25. Fenton E. Personal Protective Equipment for front-line health workers: an ethical imperative. J Med Ethics 2020 https://blogs.bmj. com/medical-ethics/2020/03/31/personal-protective-equipmentfor-front-line-health-workers-an-ethical-imperative/?int source=trendmd\&int_campaign=usage-042019\&int_medium $=c p c$ Erişim tarihi: 01.06.2020

26. Schuklenk U. Health Care Professionals Are Under No Ethical Obligation to Treat COVID-19 Patients. J Medical Ethics 2020. https://blogs.bmj.com/medical-ethics/2020/04/01/health-careprofessionals-are-under-no-ethical-obligation-to-treat-covid-19patients/ Erişim tarihi: 01.06.2020

27. American College of Emergency Physicians ACEP Policy Statement, Code of Ethics; January 2017. p.13. https://www.acep.org/ globalassets/new-pdfs/policy-statements/code-of-ethics-foremergency-physicians.pdf

28. American Medical Association (AMA) Code of Medical Ethics: Allocating Limited Health Care Resources Code of Medical Ethics Opinion 11.1.3 https://www.ama-assn.org/delivering-care/ethics/ allocating-limited-health-care-resources Erişim tarihi: 01.06.2020.

29. Emanuel E, Persad G, Upshur R, Thome B, Parker M, Glickman, A, et al. Fair Allocation of Scarce Medical Resources in the Time of Covid-19. N Engl J Med 2020;382:2049-55. [CrossRef]
30. White DB, Katz MH, Luce JM, Lo B. Who Should Receive Life Support During a Public Health, Emergency? Using Ethical Principles to Improve Allocation. Ann Intern Med 2009;150:132-8. [CrossRef]

31. World Health Organization. Guidance for managing ethical issues in infectious disease outbreaks. World Health Organization. 2016. https:// apps.who.int/iris/handle/10665/250580 Erişim tarihi: 01.06.2020.

32. Human Rights Watch, Rights Risks to Older People in COVID-19 Response Combat Ageism; Ensure Access to Health Care, Services, April 7, 2020 https://www.hrw.org/news/2020/04/07/rights-risksolder-people-covid-19-response Erişim tarihi: 01.06.2020.

33. UNESCO Report of the International Bioethics Committee on the Bioethical Response to the Situation of Refugees, SHS/YES/IBC24/17/2 REV.2 Paris, 15 September 2017. https://unesdoc.unesco. org/ark:/48223/pf0000248721 Erişim tarihi: 01.06.2020.

34. Razai MS, Oakeshott P, Kankam H, Galea S, Stokes-Lampard H. Mitigating the psychological effects of social isolation during the covid-19 pandemic. BMJ 2020;369:m1904. [CrossRef]

35. Roesch E, Amin A, Gupta J, García-Moreno G. Violence against women during covid-19 pandemic restrictions. BMJ 2020;369:m1712. [CrossRef]

36. Kadın Cinayetlerini Durduracağız Platformu, Korona Günlerinde Kadınlar için Şiddetten Korunma Kılavuzu 28.03.2020 http:// kadincinayetlerinidurduracagiz.net/aciklamalar/2899/ koronagunlerindekadinlaricin-siddetten-korunma-kilavuzu Erişim tarihi: 01.06.2020.

37. Council of Europe Oviedo Convention on Human Rights and Biomedicine https://www.coe.int/en/web/conventions/full-list/-/ conventions/treaty/164; Oviedo Convention Additional Protocol to the Convention on Human Rights and Biomedicine, concerning Biomedical Research https://www.coe.int/en/web/conventions/fulllist/-/conventions/treaty/195 M.26, Erişim tarihi: 01.06.2020

38. World Health Organization. Guidance for managing ethical issues in infectious disease outbreaks. World Health Organization. 2016. https://apps.who.int/iris/handle/10665/250580 Erişim tarihi: 01.06.2020.

39. World Medical Association Declaration of Helsinki - Ethical Principles for Medical Research Involving Human Subjects 64th WMA General Assembly, Fortaleza, Brazil, October 2013 https://www.wma.net/ policies-post/wma-declaration-of-helsinki-ethical-principles-formedical-research-involving-human-subjects/; Council of Europe Oviedo Convention on Human Rights and Biomedicine https://www. coe.int/en/web/conventions/full-list/-/conventions/treaty/164 ; Oviedo Convention Additional Protocol to the Convention on Human Rights and Biomedicine, concerning Biomedical Research https://www.coe.int/en/web/conventions/full-list/-/conventions/ treaty/195 Erişim tarihi: 01.06.2020

40. Shah SK, Miller FG, Darton TC, Duenas D, Emerson C, Lynch HF, et al. Ethics of controlled human infection to study COVID-19. Science 2020;368:832-4. [CrossRef]

41. Marmot M. Social determinants of health inequalities. Lancet. 2005;365:1099-1104. [CrossRef]

42. Godlee F. Racism: the other pandemic. BMJ 2020;369:1. [CrossRef]

43. Nuffield Council on Bioethics, Ethical considerations in responding to the COVID-19 pandemic Rapid policy briefing. https://www. nuffieldbioethics.org/assets/pdfs/Ethical-considerations-inresponding-to-the-COVID-19-pandemic.pdf Erişim tarihi: 01.06.2020. 